\title{
H2BU1 wt Allele
}

National Cancer Institute

\section{Source}

National Cancer Institute. H2BU1 wt Allele. NCI Thesaurus. Code C162986.

Human H2BU1 wild-type allele is located in the vicinity of $1 \mathrm{q} 42.13$ and is approximately 2 $\mathrm{kb}$ in length. This allele, which encodes histone H2B type 3-B protein, is involved in DNA wrapping in nucleosomes. 